\title{
ILMU JARH WA TA'DIL
}

\author{
Muh. Haris Zubaidillah \\ Email: hariszub@gmail.com
}

\begin{abstract}
Abstrak
Ilmu Al-Jarh wa At-Ta'dil adalah ilmu yang menerangkan tentang cacatcacat yang dihadapkan kepada para perawi dan tentang penta'dilannya (memandang lurus para perawi) dengan memakai kata-kata yang khusus dan untuk menerima atau menolak riwayat mereka. Ilmu ini tumbuh bersama-sama dengan tumbuhnya periwayatan dalam Islam, karena untuk mengetahui hadis-hadis yang shahih perlu mengetahui keadaan rawinya, secara yang memungkinkan ahli ilmu menetapkan kebenaran rawi atau kedustaanya hingga dapatlah merasa antara yang diterima dengan yang ditolak. Karena itu para ulama menanyakan keadaan para perawi, meneliti kehidupan ilmiyah mereka, agar mengetahui siapa yang lebih hafal dan kuat ingatannya. Adapun kegunaan dari Ilmu Al Jarh wa Ta'dil untuk menentukan kualitas perawi dan nilai hadisnya. Menetapkan apakah periwayatan seorang perawi itu bisa diterima atau ditolak sama sekali.
\end{abstract}

Kata Kunci: ilmu, jarh, ta'dil

\section{A. Pendahuluan}

Tidak semua hadis itu bersifat terpuji perawinya dan tidak semua hadis-hadis itu bersifat dhaif perawinya, oleh karena itu para periwayat mulai dari generasi sahabat sampai dengan generasi mukharrijul hadis tidak bisa kita jumpai secara fisik karena mereka telah meninggal dunia. Untuk mengenali keadaan mereka, baik kelebihan maupun kekurangan mereka dalam periwayatan, maka diperlukanlah informasi dari berbagai kitab yang di tulis oleh ulama ahli kritik para periwayat hadis.

Kritikan para periwayat hadis itu tidak hanya berkenaan dengan hal-hal yang terpuji saja tetapi juga mengenai hal-hal yang tercela. Hal-hal dapat dikemukakan untuk dijadikan pertimbangan dalam hubungannya dengan dapat atau tidak diterimanya riwayat hadis yang mereka riwayatkan. Untuk itulah lebih jelasnnya disini penulis akan membahas tentang “Ilmu Jarh Wa Ta'dil.” 


\section{B. Pengertian Al-Jarh Wat-Ta'dil}

Al-Jarh secara bahasa merupakan isim mashdar yang berarti luka yang mengalirkan darah atau sesuatu yang dapat menggugurkan ke'adalaban seseorang

- Al-Jarb menurut istilah yaitu terlihatnya sifat pada seorang perawi yang dapat menjatuhkan ke'adalahannya, dan merusak hafalan dan ingatannya, sehingga menyebabkan gugur riwayatnya, atau melemahkannya hingga kemudian ditolak.

- At-Tajrih yaitu memberikan sifat kepada seorang perawi dengan sifat yang menyebabkan pendla'ifan riwayatnya, atau tidak diterima riwayatnya.

- Al-Adlu secara bahasa adalah apa yang lurus dalam jiwa; lawan dari durhaka. Dan seorang yang 'adil artinya kesaksiannya diterima; dan At-Ta'dil artinya mensucikannya dan membersihkannya.

- Al-Adlu menurut istilah adalah orang yang tidak nampak padanya apa yang merusak agamanya dan perangainya, maka oleh sebab itu diterima beritanya dan kesaksiannya apabila memenuhi syarat-syarat menyampaikan hadits (yaitu : Islam, baligh, berakal, dan kekuatan hafalan).

- At-Ta'dil yaitu pensifatan perawi dengan sifat-sifat yang mensucikannya, sehingga nampak ke'adalabannya, dan diterima beritanya. ${ }^{1}$

Lebih jelasnya, ilmu pengetahuan yang membahas tentang kritikan adanya 'aib atau memberikan pujian adil kepada seorang rawi disebut dengan "Ilmu Jarh wa alTa;dil".

Dr. Ajjaj Khatib mendefinisikannya sebagai berikut:

$$
\text { هو العلم الذي يبحث في أحوال الرواة من حيث قبول روايتهم أوردها. }
$$

"Ialah suatu ilmu yang membahas hal ibwal para rawi dari segi diterima atau ditolake periwayatanny". ${ }^{2}$

Ulama lain mendefinisikan al-jarb wa al Ta'dil dengan:

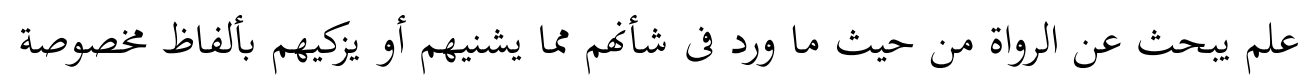
2005) h. 78

${ }^{1}$ Syaikh Manna Al-Qaththan, Pengantar Studi Imu Hadits, (Jakarta Timur: Pustaka Al-Kautsar,

${ }^{2}$ Fatchur Rahman, Ikbtisar Mushthalabu'l-Hadits,Cet. Ke-1, (Bandung: PT Al-Ma'arif, 1974), h. 
"Ilmu yang membahas tentang para perawi hadis dari segi yang dapat menunjukan keadaan mereka, baik yang dapat mencacatkan atau mebersibkan mereka, dengan ungkapan atau lafadz tertentu". ${ }^{3}$

Dari definisi di atas dapat dismpulkan bahwa ilmu Al-Jarh wat-Ta'dil adalah ilmu yang menerangkan tentang cacat-cacat yang dihadapkan kepada para perawi dan tentang penta'dilannya (memandang lurus perangai para perawi) dengan memakai katakata yang khusus dan untuk menerima atau menolak riwayat mereka.

Para ulama menganjurkan untuk melakukan jarb dan ta'dil, dan tidak menganggap hal itu sebagai perbuatan ghibah yang terlarang; diantaranya berdasarkan dalil-dalil berikut :

- Sabda Rasulullah shallallaahu 'alaihi wasallam kepada seorang laki-laki : "(Dan) itu seburuk-buruk saudara di tengah-tengah keluarganya”. (HR. Bukhari).

- Sabda Rasulullah shallallaahu 'alaihi wasallam kepada Fathimah binti Qais yang menanyakan tentang Mu'awiyyah bin Abi Sufyan dan Abu Jahm yang tengah melamarnya : "Adapun Abu Jahm, dia tidak pernah meletakkan tongkat dari pundaknya (suka memukul), sedangkan Mu'awiyyah seorang yang miskin tidak mempunyai barta" (HR. Muslim).

Dua hadits di atas merupakan dalil Al-Jarh dalam rangkan nasihat dan kemaslahatan. Adapun At-Ta'dil, salah satunya berdasarkan hadits :

Rasulullah shallallaahu 'alaihi wasallam bersabda : "Sebaik-baik hamba Allah adalah Khalid bin Walid, salah satu pedang diantara pedang-pedang Allab" (HR. Ahmad dan Tirmidzi dari Abi Hurairah radliyallaahu 'anhu).

Oleh karena itu, para ulama membolehkan Al-Jarh wat-Ta'dil untuk menjaga syari'at/agama ini, bukan untuk mencela manusia. Dan sebagaimana dibolehkan Jarh dalam persaksian, maka pada perawi pun juga diperbolehkan; bahkan memperteguh dan mencari kebenaran dalam masalah agama lebih utama daripada masalah hak dan harta.

${ }^{3}$ Mudasir, "Tlmu Hadits", (Bandung: Pustaka Setia), 1999, h.51 


\section{Perkembangan Ilmu Al-Jarh wa At-Ta'dil}

Ilmu ini tumbuh bersama-sama dengan tumbuhhnya periwayatan dalam Islam, karena untuk mengetahui hadis-hadis yang shahi perlu mengetahui keadaan rawinya, secara yang memungkinkan ahli ilmu menetapkan kbenaran rawi atau kedustaanya hingga dapatlah membedakan antara yang diterima dengan yang ditolak.

Awal mula pertumbuhan ilmu ini adalah seperti yang dinukil oleh nabi shallaulahu Alaihi wa Sallam sebagamana yang telah disebutkan tadi. Lalu menjadi banyak dari para sahabat, tabi'in, dan orang setalah mereka, karena takut terjadi seperti apa yang diperingatkan oleh Rasulullah.

Al-Jarh dan At-Ta'dil dalam ilmu hadits menjadi berkembang di kalangan shahabat, tabi'in, dan para ulama setelahnya hingga saat ini karena takut pada apa yang diperingatkan Rasulullah shallallaahu 'alaihi wasallam : "Akan ada pada umatku yang terakbir nanti orang-orang yang menceritakan badits kepada kalian apa yang belum pernah kalian dan juga bapak-bapak kalian mendengar sebelumnya. Maka waspadalah terhadap mereka dan waspadailah mereka" (HR. Muslim).

Dari Yahya bin Sa'idAl-Qaththan dia berkata,"Aku telah bertanya kepada Sufyan Ats-Tsaury, Syu'bah, dan Malik, serta Sufyan bin 'Uyainah tentang seseorang yang tidak teguh dalam hadits. Lalu seseorang datang kepadaku dan bertanya tentang dia, mereka berkata,"Kabarkanlah tentang dirinya bahwa baditsnya tidaklah kuat" (HR. Muslim).

Dari Abu Ishaq Al-Fazary dia berkata,"Tulislah dari Baqiyyah apa yang telah ia riwayatkan dari orang-orang yang dikenal, dan jangan engkau tulis darinya apa yang telah dia riwayatkan dari orang-orang yang tidak dikenal, dan janganlah kamu menulis dari Isma'il bin 'Iyasy apa yang telah ia riwayatkan dari orang-orang yang dikenal maupun dari selain mereka" (- Baqiyyah bin Al-Walid banyak melakukan tadlis dari para dlu'afaa). ${ }^{4}$

Diketahuinya hadits-hadits yang shahih dan yang lemah hanyalah dengan penelitian para ulama' yang berpengalaman yang dikaruniai oleh Allah kemampuan

${ }^{4}$ Muhammad Hasbi Ash Shiddieqy, Sejarah dan pengantar Ilmu Hadits, (Semarang: PT. Pustaka riski Putra, 1997) h. 98 
untuk mengenali keadaan para perawi. Dikatakan kepada Ibnul-Mubarak : "Bagaimana dengan) badits-badits yang dipalsukan ini?". Dia berkata, "Para ulama yang berpengalaman yang akan menghadapinya".

Maka penyampaian hadits dan periwayatannya itu adalah sama dengan penyampaian untuk agama. Oleh karenannya kewajiban syar'i menuntut akan pentingnya meneliti keadaan para perawi dan keadilan mereka, yaitu seorang yang amanah, alim terhadap agama, bertaqwa, hafal dan teliti pada hadits, tidak sering lalai dan tidak peragu. Melalaikan itu semua (Al-Jarh wat-Ta'dil) akan menyebabkan kedustaan kepada Rasulullah shallallaahu 'alaihi wasallam. ${ }^{5}$

\section{Kegunaan Ilmu Al jarh wa Ta'dil}

Ilmu jarh wa al-ta'dil sangat berguna untuk menentukan kualitas perawi dan nilai hadisnya. Membahas sanad terlebih dahulu harus mempelajari kaidah-kaidah ilmu jarb wa al-ta'dil yang telah banyak dipakai para ahli, mengetahui syarat-syarat perawi yang dapat diterima, cara menetapkan keadilan dan kedhabitan perawi dan hal-hal lain yang berhubungan dengan bahasan ini. Seseorang tidak akan dapat memperoleh biografi, jika mereka tidak terlebih dahulu mengetahui kaidah-kadah jarb dan ta'dil, maksud dan derajat (tingkatan) istilah yang dipergunakan dalam ilmu ini, dari tingkatan ta'dil yang tertinggi sampai pada tingkatan jarb yang paling rendah. ${ }^{6}$

Jelasnya ilmu jarb wa ta'dilini dipergunakan untuk menetapkan apakah periwayatan seorang perawi itu bisa diterima atau harus ditolak sama sekali. Apabila seorang perawi "dijarb" oleh para ahli sebagai rawi yang cacat, maka periwayatannya harus ditolak. Sebaliknya bila dipuji maka hadisnya bisa diterima selama syarat-syarat yang lain dipenuhi.

Adapun informasi jarb dan $t a^{\prime}$ dilnya seorang rawi bisa diketahui melalui dua jalan, yaitu: ${ }^{7}$

5An Nawawi Iman, “dasar-dasar Ilmu Hadis”, (Jakarta: Pustaka Firdaus, 1998) h.40

'Dr. Mahmud at- Thahan, "Metode Takbrij dan Penelitian Sanad Hadits", Surabaya: PT Bina Ilmu,

${ }^{7}$ Drs. Munzier Suparta, "Tlmu Hadits”, Jakarta : PT Raja Grafindo, Persada, h. 33 
a. Popularitas para perawi di kalangan para ahli ilmu bahwa mereka dikenal sebagai orang yang adil, atau rawi yang mempunyai 'aib. Bagi yang sudah terkenal dikalangan ahli ilmu tentang keadilannya, maka mereka tidak perlu lagi diperbincangkan lagi keadilannya, begitu juga dengan perawi yang terkenal dengan kefasikan atau dustanya maka tidak perlu lagi dipersoalkan.

b. Berdasarkan pujian atau pen-tarjih-an dari rawi lain yang adil. Bila seorang rawi yang adil menta'dilkan seorang rawi yang lain yang belum dikenal keadiannya, maka telah dianggap cukup dan rawi tersebut bisa menyandang gelar adil dan periwayatannya bisa di terima. Begitu juga dengan rawi yang di tarjih. Bila seorang rawi yang mentarjihnya maka periwayatannya menjadi tidak bisa diterima.

Sementara orang yang melakukan $t a^{\prime} d i l$ dan tarjih harus memenuhi syarat sebagai berikut: berilmu pengetahuan, taqwa, wara', jujur, menjaubi sifat fanatik terbadap golongan dan mengetahui ruang lingkup ilmu jarb dan ta'dil ini.

\section{E. Sebab-Sebab Perawi Dikenakan Jarh Dan Ta'dil}

Menurut Ibn Hajar al-Asqolani, sebagaimana dikutip Hasbi, bahwa sebabsebab yang menjadikan aibnya seoarang perawi itu banyak, tetapi semuanya berkisar disekitar lima macam saja: bid'ah, mukhlafah, ghalath, jahalah al-hal, da'wa al-inqitha. ${ }^{8}$

Bid'ah yaitu melakukan tindakan tercela diluar ketentuan syara. Orang yang disifati dengan bid'ah adakalanya tergolong orang yang dikafirkan dan adakalanya orang yang difasikan. Mereka yang dianggap kafir adalah golongan Rafidhah dan mereka yang dianggap fasik adalah golongan yang mempunyai keyakinan (itikad) yang berlawanan dengan dasar syari'at.

> Mukhalafah ialah menyalahi periwayatan orang yang lebih tsiqat. Mukhalafah ini dapat menimbulkan haditsnya syadz atau munkar.

> Yang dimaksud dengan ghalath ialah banyak kekeliruan dalam meriwayatkan.

> Jahalah al-hal ialah tidak dikenal identitasnya, maksud perawi yang belum dikenal identitasnya ialah haditsnya tidak dapat diterima. 
Sedangkan Da'wa al-“inqitha' ialah diduga keras sanadnya terputus, misalnya menda'wa perawi, mentadliskan atau mengirsalkan suatu hadits.

\section{F. Syarat Seorang Kritikus}

Mengingat perjalanan (pekerjaan) melakukan jarh dan ta'dil ini merupakan pekerjaan yang rawan, karena menyangkut nama baik dan kehormatan para perawi yang akan menentukan diterima atau ditolaknya suatu hadits, maka ulama yang menetapkan kriteria tertentu bagi seorang yang melakukan jarh dan ta'dil. Adapun syarat-syarat yang diperlukan, yakni:

Haruslah orang tersebut 'âlim (berilmu pengetahuan),

$>$ Bertaqwa,

> Wara' (orang yang selalu menjauhi perbuatan maksiat, syubhat-syubhat, dosa-dosa kecil dan makruhat-makruhat),

$>$ Jujur,

$>$ Belum pernah dijarh,

$>$ Menjauhi fanatik golongan,

$>$ Mengetahui sebab-sebab untuk men-ta'dilkan dan untuk men-tajrihkan.

Apabila persyaratan-persyaratan ini tidak terpenuhi maka periwayatan tidak diterima.

\section{G. Tinkatan-tingkatan Al-Jarh Wat-ta'dil}

Para perawi yang meriwayatkan hadits bukanlah semuanya dalam satu derajat dari segi keadilannya, kedlabithannya, dan hafalan mereka. Di antara mereka ada yang hafalannya sempurna, ada yang kurang dalam hafalan dan ketepatan, dan ada pula yang sering lupa dan salah padahal mereka orang yang 'adil dan amanah; serta ada juga yang berdusta dalam hadits. Maka Allah menyingkap perbuatannya ini melalui tangan para ulama' yang sempurna pengetahuan mereka. Oleh karena itu, para ulama' menetapkan tingkatan Jarh dan Ta'dil, dan lafadh-lafadh yang menunjukkan pada setiap tingaktan. Tingkatan Ta'dil ada enam tingkatan, begitu pula dengan Jarh (ada enam tingkatan).

${ }^{9}$ Fatchur Rahman, Ikbtisar Mushthalabu'l-Hadits....... h. 310-311. 


\section{Tingkatan At-Ta'dil}

Tingkatan Pertama, Yang menggunakan bentuk superlatif dalam penta'dil-an, atau dengan menggunakan wazan af'ala dengan menggunakan ungkapan-ungkapan seperti : "Fulan kepadanyalah puncak ketepatan dalam periwayatan" atau "Fulan yang paling tepat periwayatan dan ucapannya" atau Fulan orang yang paling kuat hafalan dan ingatannya".

Tingkatan Kedua, Dengan menyebutkan sifat yang menguatkan ke-tsiqah-annya, ke-'adil-annya, dan ketepatan periwayatannya, baik dengan lafadh maupun dengan makna; seperti : tsiqatun-tsiqah, atau tsiqatun-tsabt, atau tsiqah dan terpercaya (ma'mun), atau tsiqah dan hafižb.

Tingkatan Ketiga, Yang menunjukan adanya pentsiqahan tanpa adanaya penguatan atas hal itu, seperti: tsiqah, tsabat, atau hafizh.

Tingkatan Keempat, Yang menunjukkan adanya ke-'adil-an dan kepercayaan tanpa adanya isyarat akan kekuatan hafalan dan ketelitian. Seperti : Shaduq, Ma'mun (dipercaya), mahallubu ash-shidq (ia tempatnya kejujuran), atau laa ba'sa bibi (tidak mengapa dengannya). Khusus untuk Ibnu Ma'in kalimatlaa ba'sa bibi adalah tsigah (Ibnu Ma'in dikenal sebagai ahli hadits yang mutasyaddid, sehingga lafadh yang biasa saja bila ia ucapkan sudah cukup untuk menunjukkan ketsqaban perawi tersebut).

Tingkatan Kelima, Yang tidak menunjukkan adanya pentsiqahan ataupun celaan; seperti : Fulan Syaikh (fulan seorang syaikh), ruwiya 'anhul-hadiits (diriwayatkan darinya hadits), atau hasanul-hadiits (yang baik haditsnya).

Tingkatan Keenam, Isyarat yang mendekati celaan (jarh), seperti: ShalihulHadiits (haditsnya lumayan), atau yuktabu badiitsubu (ditulis haditsnya.)

\section{Hukum Tingkatan-Tingkatan Ini}

> Untuk tiga tingkatan pertama, dapat dijadikan hujjah, meskipun sebagian mereka lebih kuat dari sebagian yang lain.

$>$ Adapun tingkatan keempat dan kelima, tidak bisa dijadikan hujjah. Tetapi hadits mereka boleh ditulis, dan diuji kedlabithan mereka dengan membandingkan hadits 
mereka dengan hadits-hadits para tsiqah yang dlabith. Jika sesuai dengan hadits mereka, maka bisa dijadikan hujjah. Dan jika tidak sesuai, maka ditolak.

Sedangkan untuk tingkatan keenam, tidak bisa dijadikan hujjah. Tetapi hadits mereka ditulis untuk dijadikan sebagai pertimbangan saja, bukan untuk pengujian, karena mereka tidak dlabith. ${ }^{10}$

\section{Tingkatan Al-Jarh}

Tingkatan Pertama, Yang menunjukkan adanya kelemahan, dan ini yang paling rendah dalam tingkatan al-jarb seperti : layyinul-hadiits (lemah haditsnya), atau fiibi maqaal (dirinya diperbincangkan), atau fiibi dla'fun (padanya ada kelemahan).

Tingkatan Kedua, Yang menunjukkan adanya pelemahan terhadap perawi dan tidak boleh dijadikan sebagai hujjah; seperti : "Fulan tidak boleh dijadikan hujjah", atau "dla'if, atau "ia mempunyai hadits-hadits yang munkar", atau majbul (tidak diketahui identitas/kondisinya).

Tingkatan Ketiga, Yang menunjukkan lemah sekali dan tidak boleh ditulis haditsnya, seperti : "Fulan dla'if jüddan (dla'if sekali)", atau "tidak ditulis haditsnya", atau "tidak halal periwayatan darinya", atau laisa bi-syai-in (tidak ada apa-apanya). (Dikecualikan untuk Ibnu ma'in bahwasannya ungkapan laisa bisyai-in sebagai petunjuk bahwa hadits perawi itu sedikit).

Tingkatan Keempat, Yang menunjukkan tuduhan dusta atau pemalsua hadits, seperti : Fulan muttaham bil-kadzib(dituduh berdusta) atau "dituduh memalsukan hadits", atau "mencuri hadits", atau matruk (yang ditinggalkan), ataulaisa bi tsiqah (bukan orang yang terpercaya).

Tingkatan Kelima, Yang menunjukkan sifat dusta atau pemalsu dan semacamnya; seperti : kadzdrab (tukang dusta), atau dajjal, atau wadldla' (pemalsu hadits), atau yakdziib (dia berbohong), atau yadla' (dia memalsikan hadits).

Tingkatan Keenam, Yang menunjukkan adanya dusta yang berlebihan, dan ini seburuk-buruk tingkatan; seperti : "Fulan orang yang paling pembohong", atau "ia adalah puncak dalam kedustaan", atau "dia rukun kedustaan".

${ }^{10}$ Fatchur Rahman, Ikbtisar Mushthalabu'l-Hadits...... h. 268 


\section{Hukum Tingkatan-Tingkatan Al-Jarh}

> Untuk dua tingkatan pertama tidak bisa dijadikan sebagai hujjah terhadap hadits mereka, akan tetapi boleh ditulis untuk diperhatikan saja. Dan tentunya orang untuk tingkatan kedua lebih rendah kedudukannya daripada tingkatan pertama.

$>$ Sedangkan empat tingkatan terakhir tidak boleh dijadikan sebagai hujjah, tidak boleh ditulis, dan tidak dianggap sama sekali. ${ }^{11}$

\section{H. Pertentangan Jarh dan Ta'dil}

Diantara para ulama terkadang terjadi pertentangan pendapat terhadap seorang perawi. Ulama yang satu menta'dilkannya sedangkan yang lainnya mentajrihnya.

Apabila dipilih permasalahan di atas maka dapat dibagi kedalam dua kategori. Pertama, pertentangan ulama itu diketahui sebabnya dan kedua pertentangan itu tidak diketahui sebabnya.

Adapun terhadap kategori yang pertama, sebab-sebab terjadinya:

1. Terkadang sebagian ulama mengenal seorang perawi, ketika perawi masih fasik, sehingga mereka mentarjih (mentajrih) perawi tersebut. Sebagian ulama lainnya mengetahui perawi itu setelah ia (perawi etersebut) bertaubat, sehingga mereka menta'dilkannya. Menurut Ajaj al-Khatib sebenarnya hal tersebut bukanlah suatu pertentangan artinya jelas yang dimenangkan adalah ulama yang menta'dil.

2. Terkadang pula ada ulama yang mengetahui perawi sebagai orang yang daya hafalnya lemah, sehingga mereka mentajrih perawi itu. Sementara ulama yang lainnya mengetahui perawi itu sebagai orang yang dhabith, sehingga mereka menta'dilkannya.

Namun dalam hal sebab-sebab pertentangan ulama mengenai jarh dan ta'dilnya seorang perawi yang tidak dapat dikompromikan, maka untuk menentukan mana yang akan diunggulkan apakah pendapat ulama yang mentajrih atau yang menta'dil terdaapat berbagai pendapat dikalangan ulama hadits, sebagai berikut:

11 Mahmud Ath-Thahan, Taisir Musthalah Al-Hadits, h. 152-154. As-Suyuti, Tadrib ar-Rawi, h. $229-233$. 
1. Jarh didahulukan dari ta'dil meskipun ulama yang menta'dilnya lebih banyak dari ulama yang mentajrih. Menurut al-Syaukani pendapat ini adalah pendapat jumhur, alasanya orang yang mentajrih mempunyai kelebihan mengetahui (cermat) melihat kekurangan perawi yang hal ini umumnya tidak dilihat secara jeli oleh orang yang menta'dil.

2. Ta'dil didahulukan dari jarh apabila orang yang menta'dil lebih banyak dari ulama yang mentajrih, karena banyaknya yang menta'dil memperkuat keadaan mereka. Pendapat ini kemudian ditolak dengan alasan bahwa meskipun ulama yang menta'dil itu banyak, namun mereka tidak mungkin akan mau menta'dil sesuatu yang telah ditajrih oleh ulama lain.

3. Apabila jarh dan ta'dil saling bertentangan maka tidak dapat ditajrihkan salah satunya, kecuali ada salah satu yang menguatkannya, dengan demikian terpaksa kitatawaquf dari mengamalkan salah satunya sampai diketemukan hal yang menguatkan salah satunya.

4. Ta'dil harus di dahulukan dari jarh, karena pentarjih dalam mentajrih perawi menggunakan ukuran yang bukan substansi jarh, sedangkan menta'dil, kecuali setelah meneliti secara cermat persyaratan diterimanya ke'adalahannya seorang perawi.

Menurut Ajaz al-Khatib pendapat pertamalah yang dipegangi oleh ulama hadits, baik mutaqaddimin maupun mutaakhirin. ${ }^{12}$

\section{Kitab-Kitab yang membahas Tentang Al-Jarh wat-Ta'dil}

Penyusunan karya dalam ilmu Al-Jarh wat-Ta'dil telah berkembang sekitar abad ketiga dan keempat, dan komentar orang-orang yang berbicara mengenai para tokoh secara jarb dan ta'dil sudah dikumpulkan. Dan jika permulaan penyusunan dalam ilmu ini dinisbatkan kepada Yahya bin Ma'in, Ali bin Al-Madini, dan Ahmad bin Hanbal; maka penyusunan secara meluas terjadi sesudah itu, dalam karya-karya yang mencakup perkataan para generasi awal tersebut.

12 Ajaz al-Khatib, "Ulum al-Hadits Ulumubu wa Musthalabubu, (Damaskus: Dar al-Fikr, 1975), 
Macam-macam kitab Jarh wa al ta'dil banyak sekali, diantaranya:

1. Kitab yang hanya menjelskan ketsiqahan perawi.

2. Buku yang hanya menjelaskan kelemahan dan kecacatan perawi.

3. Buku yang menjelaskan ketsiqahan dan kelemahan rawi, dari asfek lain, sebagian kitab tentang Jarh wa al- Ta'dil umumnya menceritakan para perawi hadis mengesampingkan penilaian terhadap tokoh-tokoh buku.

Sebagian besar metode yang dipakai oleh para pengarang adalah mengurutkan nama para perawi sesuai dengan huruf kamus (mujjam). Dan berikut ini karya-karya mereka yang sampai kepada mereka :

a. Ma'rifat ar-Rijal, karya Yahya Ibni Main (wafat tahun $233 \mathrm{H}$ ). Berada di Darul kutub Adh- Dhahiriyah.

b. Adl-Dlu'afaa'ul-Kabiir dan Adl-Dlu'afaa'ush-Shaghiir, karya Imam Muhammad bin Isma'il Al-Bukhari (wafat tahun $256 \mathrm{H}$ ), dicetak di India tahun $320 \mathrm{H}$. Karya beliau yang lain : At-Tarikh Al-Kabiir, Al-Ausath, dan Ash-Shaghiir].

c. Al-Jarbu wa at Ta'dil, karya Abdur Rahman bin Abi Hatim Ar-Razy.

d. Al-Tsiqat, karya Ibnu Hatim bin Hibban al- Busty. Naskah aslinya di Darul kutub al- Mishriyyah.

e. Ats-Tsiqaat, karya Abul-Hasan Ahmad bin Abdillah bin Shalih Al-'Tjly (wafat tahun $261 \mathrm{H})$, manuskrip.

f. Mizan al-I'tidal, karya Imam Syamuddin Muhammad adz- Dzahaby.

g. Lisan al-Mizan, karya al- Hafidz Ibnu Hajar al- Asqalany, dicetak di India tahun $1329-1331 \mathrm{H}$

h. Tabdib al- Tahdib, karya Ibnu Hajar.

i. Al-Kamal fi Asma ar-Rijal, karya Abdul Ghani Mudadisy.

\section{J. Kesimpulan dan Saran}

Maka ilmu Al-Jarh wa At-Ta'dil adalah ilmu yang menerangkan tentang cacatcacat yang dihadapkan kepada para perawi dan tentang penta'dilannya (memandang lurus para perawi) dengan memakai kata-kata yang khusus dan untukmenerima atau menolak riwayat mereka. 
Ilmu ini tumbuh bersama-sama dengan tumbuhnya periwayatan dalam Islam, karena untuk mengetahui hadis-hadis yang shahih perlu mengetahui keadaan rawinya, secara yang memungkinkan ahli ilmu menetapkan kebenaran rawi atau kedustaanya hingga dapatlah merasa antara yang diterima dengan yang ditolak.

Karena itu para ulama menanyakan keadaan para perawi, meneliti kehidupan ilmiyah mereka, agar mengetahui siapa yang lebih hafal dan kuat ingatannya.

Adapun kegunaan dari Ilmu Al Jarh wa Ta'dil untuk menentukan kualitas perawi dan nilai hadisnya. Menetapkan apakah periwayatan seorang perawi itu bisa diterima atau ditolak sama sekali.

Ilmu jarh wa ta'dil adalah ilmu yang sangat penting bagi para pelajar ilmu hadits. karena ilmu ini merupakan timbangan bagi para rawi hadits. Rawi yang berat timbangannya diterima riwayatnya dan rawi yang ringan timbangannya ditolak riwayatannya. Dengan ilmu ini kita bisa mengetahui periwayat yang dapat diterimahadistnya, serta dapat membedakannya dengan periwayat yang tidak dapat diterimahaditsnya. Oleh karena itulah para ulama hadits memperhatikan ilmu ini dengan penuh perhatiannya dan mencurahkan segala pikirannya untuk menguasainya. 


\section{DAFTAR PUSTAKA}

Al-Khatib, Ajaz. Ushul al-hadits Ulumubu Wa Musthalahubu, Dar al-Fikr, Damaskus, 1989.

Al-Qaththan, Syaikh Manna'. Pengantar Studi Ilmu Hadits (Penj. Mifdhol Abdurrahman, Lc.), Pustaka Al-Kautsar, Jakarta, 2009.

An Nawawi Imam, "Dasar-Dasar Ilmu Hadist", Jakarta: Pustaka Firdaus.

At- Thahan Mahmud, "Metode Takhrij dan penelitian sanad hadis", Surabaya: PT Bina Ilmu,1995.

At-Thahan, Mahmud, "Taisir Musthalah al- hadis". Maktabah Syamilah

Hasbi As-shidieqy, Teungku Muhammad. Prof. Dr. "Pokok-pokok Ilmu Dirayah Hadis", jil. II Jakarta: Bulan Bintang.

Pengantar Ilmu hadits, PT. Pustaka Rizki Putra Semarang, 2010.

Ma’luf, Louis. Kamus al-Munjid,al-Mathba'ah al-Bijatsu Kuliah, Beirut, 1935.

Mudasir, "Tlmu Hadits”, Bandung: Pustaka Setia, 1999.

Rahman, Fatchur., Ikhtisar Musthalah al-Hadits, PT. Al-Ma'arif, Bandung, 1974.

Suparta , Munzier. Ilmu Hadis,Cet. Ke-6, PT. Raja Grafindo Persada, Jakarta, 2010.

Yuslem, Nawir, Dr. M.A. Sembilan Kitab Induk Hadis, Hijri Pustaka Utama, Jakarta, 2006. 